\title{
Chemical constituents of the lichen Roccella sinensis growing in Binh Thuan province
}

\author{
Duong Thuc Huy, Bui Xuan Hao
}

\begin{abstract}
The lichen Roccella sinensis has not been studied chemically. This research described the isolation and elucidation of compounds isolated from the lichen Roccella sinensis collected in Binh Thuan. Phytochemistry investigation of this lichen was carried out by using normal phase silica gel column chromatography and thin-layer chromatography. Six compounds was isolated. Their structures were established by extensively spectroscopic analysis as well as comparison with NMR data in the literatures. They are (+)-D-montagnetol (1), (+)-D-erythrin (2), lecanorin (3), 1-acetylerythritol (4), (E)-nostodione A (5), and 2,4-dihydroxyphthalide (6). This is the first time compounds 3-6 were found in the Roccella genus. Compounds 1, 2, and 6 were evaluated for their cytotoxic activities against HepG2 (liver hepatocellular carcinoma), NCI-H460 (human lung cancer), MCF-7 (human breast cancer), and HeLa (human epithelial cancer) and all of them showed no activity.
\end{abstract}

Keyword - Roccella sinensis, lichen, erythrin, montagnetol

\section{INTRODUCTION}

$\mathrm{L}$ ichens are symbiotic products of the mycobiont (fungal partner) and photobiont (algal partner) [1]. The genus Roccella includes 24 species which are restricted to coastal habitats [2]. Phytochemical studies on lichens Roccella spp. have been conducted over forty years on seven Roccella lichens [1] and the results showed that these lichens produced a diverse range of metabolites as meso-erythritol, dibenzofurans, chromones, amino acids, carbohydrates, ergosterol, and $\beta$-carotene. Among them, erythrin and lecanoric acid were found in most of Roccella

Received 24-11-2017; Accepted 07-01-2018; Published 2011-2018

Duong Thuc Huy, Bui Xuan Hao - Ho Chi Minh City University of Education

*Email:huydt@hcmue.edu.vn species [2] and the former was reported as a principal secondary product $[3,4]$ and the content of this compound was $7.3 \%$ in $R$. montagnei [5]. The lichen Roccella sinensis is distributed commonly in Binh Thuan province, Vietnam. This lichen has not yet been chemically studied. The phytochemical study on the lichen $R$. sinensis led to the isolation of six compounds, including (+)-D-montagnetol (1), (+)-D-erythrin (2), lecanorin (3), 1-acetylerythritol (4), (E)nostodione A (5), and 2,4-dihydroxyphthalide (6) (Fig. 1). Herein we describe the isolation and structural elucidation of these compounds as well as the cytotoxic evaluation of some isolated compounds.

\section{MATERIALS AND METHODS}

\section{Plant material}

Roccella sinensis was collected on the unknown trees in Lien Huong temple, Lien Huong district, Binh Thuan province. A voucher specimen (No US-B024) was deposited in the herbarium of the Department of Organic Chemistry, University of Science. Its scientific name was determined Dr. Wetchasart Polyiam, Lichen Research Unit, Department of Biology, Faculty of Science, Ramkhamhaeng University, Thailand.

\section{General experimental procedures}

The NMR spectra were recorded on a Bruker Avance III (500 MHz for ${ }^{1} \mathrm{H}$ NMR and $125 \mathrm{MHz}$ for ${ }^{13} \mathrm{C}$ NMR) spectrometer. Proton chemical shifts were referenced to the solvent residual signal of $\mathrm{CD}_{3} \mathrm{COCD}_{3}$ at $\delta_{\mathrm{H}} 2.05$ and of $\mathrm{CD}_{3} \mathrm{SOCD}_{3}$ at $\delta_{\mathrm{H}} 2.50$. The ${ }^{13} \mathrm{C}-\mathrm{NMR}$ spectra were referenced to the central peak of of $\mathrm{CD}_{3} \mathrm{COCD}_{3}$ at $\delta_{\mathrm{C}} 29.4$ and of $\mathrm{CD}_{3} \mathrm{SOCD}_{3}$ at $\delta_{\mathrm{C}}$ 39.5. The HR-ESI-MS were recorded on a HRESI-MS Bruker microOTOF Q-II. Gravity 
column chromatography was performed with Silica gel 60 (0.040-0.063 mm, Himedia).

\section{Extraction and isolation}

The clean, air-dried and ground material $(1.7 \mathrm{~kg})$ was extracted by maceration with methanol (3x5 L) at the ambient temperature, and the filtrated solution was concentrated under the reduced pressure to afford the crude extract $(450 \mathrm{~g})$. This crude extract was applied to normal phase silica gel column chromatography, eluting with the solvent system $n$-hexane: ethyl acetate $(9: 1$ to $0: 10)$ to afford the extracts, H (10.2 g), EA1 (21.1 g), EA2 (66.1 g), EA3 (29.8 g) and EA4 (64.2 g). The extract EA1 (21.1 g) was applied to silica gel column chromatography (CC), eluted stepwise with $n$-hexane: ethyl acetate: acetic acid (9:1:0.020:10:0.02) to give three fractions EA1.1 (2.8 g), EA1.2 (15.1 g) and EA1.3 (1.1 g). Fraction EA1.1 $(2.8 \mathrm{~g})$ was fractionated, eluting with $n$-hexane: ethyl acetate: acetic acid (9:1:0.05) to afford three subfractions, EA1.1.1 (298.8 mg), EA1.1.2 (1.2 g) and EA1.1.3 (0.9 g). A part of subfraction EA1.1.2 (300 mg) was rechromatographed, eluting with $n$ hexane: ethyl acetate: acetic acid (9:1:0.04), then applied to preparative thin-layer chromatography to afford 6 (6.9 mg). Fraction EA1.2 (15.1 g) was rechromatographed, eluting with chloroform: ethyl acetate: acetone (9:1:3) to afford two compounds, 1 $(1.5 \mathrm{~g})$ and 2 (1.0 g). Extract EA2 (66.1 g) was applied to silica gel column chromatography, eluting with $n$-hexane: ethyl acetate: acetic acid from $(9: 1: 0.02)$ to $(0: 10: 0.02)$ to give two fractions EA2.1 (22.1 g) and EA2.2 (33.9 g). Subfraction EA2.1 was rechromatographed, eluting with chloroform: ethyl acetate: acetone (9:1:3) to afford two compounds, 3 (9.9 $\mathrm{mg})$ and 4 (79.7 $\mathrm{mg})$. Fraction EA4 was applied to silica gel CC to provide three subfractions EA4.1 (16.1 g), EA4.2 (25.3 g) and EA4.3 (15.2 g). Subfraction EA4.1 was further chromatographed, eluting with chloroform: ethyl acetate: acetone $(9: 1: 3)$ to afford 5 (6.1 mg).

\section{(+)-D-Montagnetol (1)}

White crystals (methanol). $[\alpha]_{\mathrm{D}}{ }^{25}+59.0$ (c 1.0, methanol). The ${ }^{1} \mathrm{H}-\mathrm{NMR}$ data (Acetone- $\left.d_{6}\right)$ : 4.62 (dd, 11.5, 3.0 Hz, H-1a), 4.45 (dd, 11.5, 6.5 Hz, H1b), 4.00 ( $t d, 7.0,2.7 \mathrm{~Hz}, \mathrm{H}-2), 3.72$ ( $m, \mathrm{H}-3), 3.84$ ( $m, \mathrm{H}-4 \mathrm{a}), 3.74$ ( $m, \mathrm{H}-4 \mathrm{~b}), 6.23$ (d, $\left.2.0 \mathrm{~Hz}, \mathrm{H}-3{ }^{\prime}\right)$, $6.27\left(d, 2.0 \mathrm{~Hz}, \mathrm{H}-5^{\prime}\right), 2.51\left(s, \mathrm{H}-8^{\prime}\right)$. The ${ }^{13} \mathrm{C}-\mathrm{NMR}$ data (Acetone- $\left.d_{6}\right): 67.8(\mathrm{C}-1), 71.0(\mathrm{C}-2), 73.1$ (C-
3), 64.3 (C-4), $105.5\left(\mathrm{C}-1^{\prime}\right), 165.9\left(\mathrm{C}-2^{\prime}\right), 101.5$ (C-3'), 163.1 (C-4'), 112.2 (C-5'), 144.6 (C-6'), 172.3 (C-7'), 24.4 (C-8'). These spectroscopic data were suitable with those reported in the literature [6].

\section{(+)-D-Erythrin (2)}

White crystals (methanol). $[\alpha]_{\mathrm{D}}^{25}+27.0(c 0.1$, methanol). The ${ }^{1} \mathrm{H}$ - NMR data (Acetone- $d_{6}$ ): 4.70 ( $d d, 11.5,3.0 \mathrm{~Hz}, \mathrm{H}-1 \mathrm{a}), 4.53$ ( $d d, 11.5,6.5$ $\mathrm{Hz}, \mathrm{H}-1 \mathrm{~b}), 4.00$ (td, 6.5, $2.5 \mathrm{~Hz}, \mathrm{H}-2), 3.70$ (m, $\mathrm{H}-3), 3.82$ ( $m, \mathrm{H}-4 \mathrm{a}), 3.74$ ( $m, \mathrm{H}-4 \mathrm{~b}), 6.75$ (d, $\left.2.5 \mathrm{~Hz}, \mathrm{H}-3^{\prime}\right), 6.79$ (d, $\left.2.5 \mathrm{~Hz}, \mathrm{H}-5^{\prime}\right), 2.59$ (s, H$\left.8^{\prime}\right), 6.30\left(d, 2.5 \mathrm{~Hz}, \mathrm{H}-3^{\prime \prime}\right), 6.37$ (d, $2.5 \mathrm{~Hz}, \mathrm{H}-$ $\left.5^{\prime \prime}\right), \quad 2.62\left(s, \quad \mathrm{H}-8^{\prime \prime}\right) . \quad$ The ${ }^{13} \mathrm{C}-\mathrm{NMR}$ data (Acetone- $\left.d_{6}\right)$ : $67.6(\mathrm{C}-1), 70.2(\mathrm{C}-2), 72.3(\mathrm{C}-3)$, 63.7 (C-4), $112.7\left(\mathrm{C}-1^{\prime}\right), 163.8\left(\mathrm{C}-2^{\prime}\right), 109.8$ (C$\left.3^{\prime}\right), 154.8$ (C-4'), 117.3 (C-5'), 144.0 (C-6'), 169.5 (C-7'), 23.7 (C-8'), 104.8 (C-1"'), 164.2 $\left(\mathrm{C}-2^{\prime \prime}\right), 101.8\left(\mathrm{C}-3^{\prime \prime}\right), 166.7\left(\mathrm{C}-4^{\prime \prime}\right), 112.9$ (C5"), 144.7 (C-6"), 170.5 (C-7"), 24.3 (C-8" $)$. These spectroscopic data were suitable with those reported in the literature [6].

\section{Lecanorin (3)}

White amorphous powder. The ${ }^{1} \mathrm{H}-\mathrm{NMR}$ data (Acetone- $\left.d_{6}\right): 6.28(d, 2.5 \mathrm{~Hz}, \mathrm{H}-3), 6.37(d, 2.5$ $\mathrm{Hz}, \mathrm{H}-5), 2.59$ ( $s, \mathrm{H}-8), 6.62$ ( $\left.t, 2.0 \mathrm{~Hz}, \mathrm{H}-1^{\prime}\right)$, $6.57\left(d, 2.0 \mathrm{~Hz}, \mathrm{H}-3^{\prime}\right), 6.57$ (d, $\left.2.0 \mathrm{~Hz}, \mathrm{H}-5^{\prime}\right)$, $2.29\left(s, \mathrm{H}-7^{\prime}\right)$. The ${ }^{13} \mathrm{C}-\mathrm{NMR}$ data (Acetone- $\left.d_{6}\right)$ : 110.6 (C-1), 164.2 (C-2), 101.9 (C-3), 159.1 (C4), 107.4 (C-5), 144.7 (C-6), 174.4 (C-7), 24.4 (C-8), 114.7 (C-1'), 154.5 (C-2'), 114.5 (C-3'), $152.0\left(\mathrm{C}^{-} 4^{\prime}\right), 112.9\left(\mathrm{C}-5^{\prime}\right), 141.1\left(\mathrm{C}-6^{\prime}\right), 21.4$ (C$\left.7^{\prime}\right)$. These spectroscopic data were suitable with those reported in the literature [7].

\section{1-Acetylerythritol (4)}

Colorless oil. The ${ }^{1} \mathrm{H}-\mathrm{NMR}$ data $\left(\mathrm{D}_{2} \mathrm{O}\right): 4.33$ (dd, 12.0, 3.0 Hz, H-1a), 4.18 (dd, 12.0, $6.5 \mathrm{~Hz}$, $\mathrm{H}-1 \mathrm{~b}), 3.87$ (ddd, 7.5, 6.5, 3.0 Hz, H-2), 3.73 (ddd, 7.5, 6.5, 3.0 Hz, H-3), 3.80 (dd, 12.0, 3.0 $\mathrm{Hz}, \mathrm{H}-4 \mathrm{a}), 3.65$ (dd, 11.5, $6.5 \mathrm{~Hz}, \mathrm{H}-4 \mathrm{~b}), 2.00$ ( $s$, AcO-). The ${ }^{13} \mathrm{C}-\mathrm{NMR}$ data $\left(\mathrm{D}_{2} \mathrm{O}\right): 66.9$ (C-1), 72.9 (C-2), 71.1 (C-3), 64.2 (C-4), 171.5 (AcO-), 20.8 (AcO-). These spectroscopic data were suitable with those reported in the literature [8].

\section{(E)-Nostodione A (5)}

Red amorphous powder. HR-ESI-MS, positive mode: $m / z \quad 312.0653 \quad[\mathrm{M}+\mathrm{Na}]^{+}$(calcd. for $\left.\mathrm{C}_{18} \mathrm{H}_{11} \mathrm{NO}_{3}+\mathrm{Na}, 312.0637\right)$. The ${ }^{1} \mathrm{H}-\mathrm{NMR}$ data 
(DMSO- $\left.d_{6}\right): 7.66(d, 8.0 \mathrm{~Hz}, \mathrm{H}-4), 7.42(t d, 7.0$, $2.5 \mathrm{~Hz}, \mathrm{H}-5), 7.33(t, 7.0 \mathrm{~Hz}, \mathrm{H}-6), 7.84$ ( $b r d, 8.0$ $\mathrm{Hz}, \mathrm{H}-7), 7.31$ (brs, H-9), $7.70(d, 8.5 \mathrm{~Hz}, \mathrm{H}-$ 11/15), $6.96(d, 8.5 \mathrm{~Hz}, \mathrm{H}-12 / 14), 10.29(s, 13-$ $\mathrm{OH})$. The ${ }^{13} \mathrm{C}-\mathrm{NMR}$ data (DMSO- $\left.d_{6}\right): 193.3$ (C-1), 119.4 (C-2), 158.6 (C-2a), 140.7 (C-3a), 114.7 (C4), 126.4 (C-5), 123.9 (C-6), 120.8 (C-7), 120.9 (C7a), 123.6 (C-7b), 177.0 (C-8), 128.8 (C-9), 124.5 (C-10), 131.7 (C-11/15), 116.4 (C-12/14), 159.8 (C-13). HMBC data: H-9 to C-1, C-2a, C-11; H-<smiles></smiles>

$11 / 15$ to C-9, C-14; H-7 to C-5, C-3a; H-4 to C6, C-3a, C-7a. These spectroscopic data were suitable with those reported in the literature [9].

\section{2,4-Dihydroxyphthalide (6)}

White amorphous powder. The ${ }^{1} \mathrm{H}-\mathrm{NMR}$ data (Acetone- $d_{6}$ ): 6.38 (brs, H-3), 6.53 (brs, H-5), $5.22(s, \mathrm{H}-8)$. These spectroscopic data were suitable with those reported in the literature [10].

Fig 1. Structure of compounds $1-6$

\section{RESULTS AND DISCUSSION}

Compounds 1-4 and 6 were identified as (+)-Dmontagnetol (1), (+)-D-erythrin (2), lecanorin (3), 1-acetylerythritol (4), and 2,4-dihydroxyphthalide (6) by comparison of their ${ }^{1} \mathrm{H}$ and ${ }^{13} \mathrm{C}$ NMR spectroscopic data as well as specific rotations with those reported in the literature. Compounds 1 and $\mathbf{2}$ were common lichen metabolites from the lichens Roccella spp. whereas compounds 3, 4, and $\mathbf{6}$ were known for the first time from this Roccella genus.

Compound 1 was obtained as white crystals (in methanol). The ${ }^{1} \mathrm{H}$ NMR spectrum showed two oxygenated methylenes and two oxygenated methines in the zone of $3.70-4.70 \mathrm{ppm}$. Additionally, 1 contained one orcinol unit, including one aromatic methyl at $\delta_{\mathrm{H}} 2.51$ and two meta-coupled protons at $\delta_{\mathrm{H}} 6.23$ and 6.27 . The ${ }^{13} \mathrm{C}$ NMR spectrum revealed two oxygenated methines $\left(\delta_{\mathrm{C}} 73.1\right.$ and 71.0), two oxygenated methylenes $\left(\delta_{\mathrm{C}} 67.8\right.$ and 64.3), two aromatic methines $\left(\delta_{\mathrm{C}} 101.5\right.$ and 112.2), two quaternary aromatic carbons ( $\delta_{\mathrm{C}} 105.5$ and 144.6), two oxygenated aromatic carbons $\left(\begin{array}{lll}\delta_{\mathrm{C}} & 163.1 & \text { and }\end{array}\right.$
165.9), one carboxyl carbon at $\delta_{\mathrm{C}} 172.3$, and one methyl group at $\delta_{\mathrm{C}} 24.4$. ${ }^{1} \mathrm{H}$ NMR chemical shifts of the methylene protons $\mathrm{H}_{2}-1$ shifted to low-field indicating that this group was esterificated. These findings implied that 1 possessed a butane1,2,3,4-tetraol pattern and an orcinol unit and these two moieties were linked together via an ester linkage. The coupling constant values of $\mathrm{H}-1$ (11.5, 3.0 Hz and 11.5, $6.5 \mathrm{~Hz})$ and $\mathrm{H}-2$ (7.0, 2.7 $\mathrm{Hz}$ ) supported the erythro configuration of the butane-1,2,3,4-tetraol pattern of $\mathbf{1}$. Comparison of the NMR data and the specific rotation of 1 $\left(\left[\alpha_{\mathrm{D}}^{25}\right]+59.0, c\right.$ 1.0, $\left.\mathrm{CH}_{3} \mathrm{OH}\right)$ with those of D- $(+)-$ montagnetol [6] showed good compatibility. Altogether, 1 was elucidated as $(+)-(2 R, 3 S)-1-$ (2,4-dihydroxy-6-methylbenzoyl)butan-1,2,3,4tetraol or (+)-D-montagnetol as shown in Fig. 1.

Compound 2 was isolated as white crystals (in methanol). The 1D-NMR spectroscopic data of 2 resembled those of lecanoric acid [1], except for the presence of signals of two oxygenated methylenes ( $\left(\delta_{\mathrm{C}} \quad 67.1\right.$ and 63.0) and two oxygentated methines ( $\delta_{\mathrm{C}} 72.4$ and 69.4). Comparison of the NMR data of the erythritol moiety of $\mathbf{1}$ and those of $\mathbf{2}$ suggested that they 
possessed the same pattern (or erythritol derivative). Detailed analysis of the coupling constant of H-2 $(\delta 3.91, t d, 7.0,3.0 \mathrm{~Hz})$ indicated that 2 also possessed the same erythro configuration as 1. Furthermore, the optical rotation of $\mathbf{2}$ was dextrorotary [6]. Accordingly, the absolute configuration $(2 R, 3 S)$ was assigned to 2. Consequently, 2 was elucidated to be $(+)$ $(2 R, 3 S)-1-[4-(2,4-d i h y d r o x y-6-m e t h y l b e n z o y l)-2-$ hydroxy-6-methyl]butan-1,2,3,4-tetraol or (+)-Derythrin as shown in Fig. 1.

Compound $\mathbf{5}$ was isolated as a red amorphous powder. The HR-ESI-MS of $\mathbf{5}$ exhibited a peak at $m / z \quad 312.0653 \quad[\mathrm{M}+\mathrm{Na}]^{+}$ indicating a molecular formula of $\mathrm{C}_{18} \mathrm{H}_{11} \mathrm{NO}_{3}$ with 14 degrees of unsaturation. The ${ }^{1} \mathrm{H} \mathrm{NMR}$, in accordance with HSQC spectra, revealed one broad singlet at $\delta_{\mathrm{H}} 7.31$, eight aromatic protons and one phenolic hydroxyl group at $\delta_{\mathrm{H}} 10.29$. In particular, two ortho coupled aromatic protons at $\delta 6.96(2 \mathrm{H}, d, 8.5 \mathrm{~Hz})$ and $7.70(2 \mathrm{H}, d, 8.5 \mathrm{~Hz})$ indicated the existence of 1,4-disubtituted D-ring. The HMBC correlation from $\mathrm{H}-12 / \mathrm{H}-14$ at $\delta_{\mathrm{H}} 6.96$ to $\mathrm{C}-13\left(\delta_{\mathrm{C}} 159.8\right)$ confirmed the position of the hydroxy group at $\mathrm{C}-13$. Moreover, the four remaining aromatic protons at $\delta_{\mathrm{H}} 7.84(\mathrm{brd}, 8.0$ $\mathrm{Hz}), 7.66(d, 8.0 \mathrm{~Hz}), 7.42(t d, 7.0,2.5 \mathrm{~Hz})$, and $7.33(t, 7.0 \mathrm{~Hz})$ were coupled with each other in an $\mathrm{AA}^{\prime} \mathrm{XX} \mathrm{X}^{\prime}$ system, confirming the 1,2disubstituted A-ring. On the basis of $\mathrm{HMBC}$, protons at $\delta_{\mathrm{H}} 7.84(\mathrm{H}-7)$ and $\delta_{\mathrm{H}} 7.33(\mathrm{H}-6)$ showed cross peaks to $\mathrm{C}-3 \mathrm{a}\left(\delta_{\mathrm{C}} 140.7\right)$, suggesting the presence of an indole-moiety. Furthermore, the ${ }^{13} \mathrm{C}$ NMR spectrum revealed two conjugated ketone signals at $\delta_{\mathrm{C}} 193.3$ and 177.0. The upfield chemical shift of $\mathrm{C}-8$ comparing to $\mathrm{C}-1$ confirmed the connectivity of this carbon to the indole moiety due to the resonance effect caused by the electron-donating nitrogen atom. The HMBC correlations showed cross peaks from $\mathrm{H}-9\left(\delta_{\mathrm{H}}\right.$ 7.31) to C-3a and C-1 and from protons $\mathrm{H}-11 / \mathrm{H}-$ $15\left(\delta_{\mathrm{H}} 7.70\right)$ to $\mathrm{C}-9$, suggesting the attachment of the D-ring to the indole ring. The spectral data comparison of $\mathbf{5}$ and the two diastereomers of nostodione A [5] indicated that 5 was $(E)$ nostodione A. Moreover, careful observation of the ${ }^{1} \mathrm{H}$ NMR spectrum indicated that there were some minor peaks belonging to the minor compound (Z)-nostodione A [5], and the integrations of some protons indicated that the ratio of the $E / Z$ isomers was $9 / 1$. Up to now, nitrogen-containing compounds from lichens was very rare with reports of several compounds [1, 11] and only one nitrogen-containing compound, a cyclopeptide was found in the Roccella genus [12]. This was the first time alkaloid $\mathbf{5}$ was reported as a lichen metabolite.

Compounds 1, 2, and $\mathbf{6}$ (at the concentration of $100 \mu \mathrm{g} / \mathrm{mL}$ ) were tested for cytotoxic activities against four cell lines MCF-7 (breast cancer cell line), HeLa (cervical cancer cell line), HepG2 (liver hepatocellular carcinoma cell line), and NCI-H460 (human lung cancer cell line) using sulforhodamine B colorimetric assay method (SRB assay) [20]. Their cytotoxic activities, expressed as a percentage of cell growth inhibition ( $\mathrm{I} \%)$, was presented in Table 1 . These major compounds had not been tested the cytotoxicity toward cancer cell lines. All three compounds failed to show any cytotoxic activity. Common lichen substances $\mathbf{3}$ and $\mathbf{4}$ were not tested for these activities.

Table 1. \% Inhibition of cytotoxic activities against four cancer cell lines of isolated compounds

\begin{tabular}{|c|c|c|c|c|c|}
\hline \multirow[t]{2}{*}{ No. } & \multirow[t]{2}{*}{ Compound $^{a}$} & \multicolumn{4}{|c|}{ Inhibition of Cell Growth (I \%) ${ }^{\mathrm{b}}$} \\
\hline & & $\mathrm{HeLa}^{\mathrm{c}}$ & $\mathrm{NCI}-\mathrm{H} 460^{\mathrm{c}}$ & $\mathrm{MCF}-7^{\mathrm{c}}$ & $\mathrm{HepG}^{\mathrm{c}}$ \\
\hline 1 & D-Montagnetol (1) & - & $20.09 \pm 1.75$ & $41.68 \pm 3.91$ & $45.56 \pm 3.13$ \\
\hline 2 & D-Erythrin (2) & $19.07 \pm 5.07$ & $25.53 \pm 3.58$ & $26.71 \pm 1.87$ & - \\
\hline \multirow[t]{2}{*}{3} & 2,4-Dihydroxyphthalide (6) & - & $10.89 \pm 0.76$ & - & - \\
\hline & Camptothecin (positive control) ${ }^{\mathrm{c}}$ & $58.2 \pm 3.3$ & $77.6 \pm 0.6$ & $41.2 \pm 2.4$ & $52.27 \pm 0.58$ \\
\hline
\end{tabular}

a) The compounds were tested at the concentration of $100 \mu \mathrm{g} / \mathrm{mL}$. b) The presented data are means of three experiments \pm S.D. c) Camptothecin was tested at the concentration of $0.01 \mu \mathrm{g} / \mathrm{mL}$ for MCF-7 and NCI-H 460, $0.07 \mu \mathrm{g} / \mathrm{mL}$ for HepG2, and of 1 $\mu \mathrm{g} / \mathrm{mL}$ for HeLa.

\section{CONCLUSION}

Six known compounds were isolated from the lichen Roccella sinensis collected in Binh Thuan 
province. This is the first time compounds lecanorin (3), 1-acetylerythritol (4), (E)nostodione A (5), and 2,4-dihydroxyphthalide (6) are reported in the genus Roccella. Compounds $\mathbf{1}$, $\mathbf{2}$, and $\mathbf{6}$ failed to reveal any cytotoxicities against four tested cancer cell lines. Further studies on this lichen are in progress.

\section{TÀI LIÊUU THAM KHẢO}

[1] S. Huneck, I. Yoshimura, "Identification of lichen substances", Springer, Berlin, 155-311 (1997).

[2] A. Tehler, M. Irestedt, M. Wedin, D. Ertz, "The old world Roccella species outside Europe and Macaronesia: taxonomy, evolution and phylogeny", Syst. Biodivers., vol. 8, pp. 223-246, 2010.

[3] G.B. Feige, B. Viethen, M. Geyer, G. Follmann, "Phytochemistry of the lichen family Roccellaceae Chev. I. Secondary products and chemotypes of Roccella hypomecha (Ach.) Bory", Journal of the Hattori Botanical Laboratory, vol. 60, pp. 143-148, 1986.

[4] D. Parrot, T. Peresse, E. Hitti, D. Carrie, M. Grube, S. Tomasi, "Qualitative and spatial metabolite profiling of lichens by a LC-MS approach combined with optimized extraction", Phytochemical Analysis, vol. 26, pp. 23-33, 2015.

[5] V.M. Thadhani, M.I. Choudhary, R.J. Andersen, V. Karunaratne, "Novel entry into 5decarboxydibenzofurans via Smiles rearrangement of the lichen para-depside, erythrin", Journal of Chemical
Research, vol. 34, pp. 154-157, 2010.

[6] J.F. Basset, C. Leslie, D. Hamprecht, A.J.P. White, A.G.M. Barrett, "Studies on the resorcylates: biomimetic total syntheses of $(+)$-montagnetol and (+)-erythrin", Tetrahedron Letters, vol. 51, pp. 783-785, 2010.

[7] I.S. Rojas, B.L. Hennsen, R. Mata, "Effect of lichen metabolites on thylakoid electron transport and photophosphorylation in isolated spinach chloroplasts", Journal of Natural Products, vol. 63, pp. 1396-1399, 2002.

[8] G.E. Hawkes, D. Lewis, " $\mathrm{H}$ nuclear magnetic resonance spectra and conformations of alditols in deuterium oxide", Journal of the Chemistry Society, Perkin Transsactions II, pp. 2073-2078, 1984.

[9] A. Ekebergh, A. Borje, J. Martensson, "Total synthesis of nostodione A, a cyanobacterial metabolite", Sweden, vol. 64, pp. 544-547, 2012.

[10] Z.Y. Ren, H.Y. Qi, Y.P. Shi, "Phytochemical investigation of Anaphalis lacteal", Planta Medica, vol. 74, pp. 859-863, 2008.

[11] T.T.T. Nguyen, M. Chollet-Krugler, F. Lohézic-Le Dévéhat, I. Rouaud, J. Boustie, "Mycosporine-like compounds in chlorolichens: Isolation from Dermatocarpon luridum and Dermatocarpon miniatum, and their photoprotective properties", Planta Med. Lett., vol. 2, pp. e1-e5, 2015.

[12] G. Bohman-Lindgren, U. Ragnarsson, "Chemical studies on lichens- XXXIV The synthesis of cyclo-(R- $\beta$-phenyl$\beta$-alanyl-L-prolyl-)2, a peptide isolated from Roccella canariensis", Tetrahedron, vol. 28, pp. 4631-4634, 1972.

\title{
Thành phần hóa học của địa y Roccella sinensis thu hái ở tỉnh Bình Thuận
}

\author{
Dương Thúc Huy, Bùi Xuân Hào \\ Trường Đại học Sư phạm TP. Hồ Chí Minh \\ Tác giả liên hệ: huydt@hcmue.edu.vn
}

Ngày nhận bản thảo 24-11-2017; ngày chấp nhận đăng 07-01-2018; ngày đăng 20-11-2018

Tóm tắt-Loài địa Roccella sinensis chưa được nghiên cứu hóa học. Nghiên cứu này mô tả sự cô lập và xác định cấu trúc của các hợp chất cô lập từ địa $y$ Rocccella sinensis thu hái ở tỉnh Bình Thuận. Khảo sát hoá học trên loài địa $\mathrm{y}$ này đã sử dụng các phương pháp sắc ký cột silica gel pha thường và sắc ký lớ mỏng. Sáu hợp chất đã được phân lập được. Cấu trúc của các hợp chất được xác định bằng các phương pháp phổ nghiệm cũng như so sánh với các dữ liệu có trong tài liệu tham khảo. Chúng là (+)-Dmontagnetol (1), (+)-D-erythrin (2), lecanorin (3), 1- acetylerythritol (4), (E)-nostodione A (5) và 2,4dihydroxyphthalide (6). Đây là lần đầu tiên các hộp chất 3-6 được biết hiện diện trong chi Roccella. Khảo sát thử nghiệm hoạt tính gây độc tế bào trên bốn dòng tế bào ung thư HeLa, HepG2, NCI-H460 and $M C F-7$ của ba hợp chất 1,2 và 6 cho thấy cả ba đều không hoạt tính.

Tù khóa-Roccella sinensis, địa y, erythrin, montagnetol 